
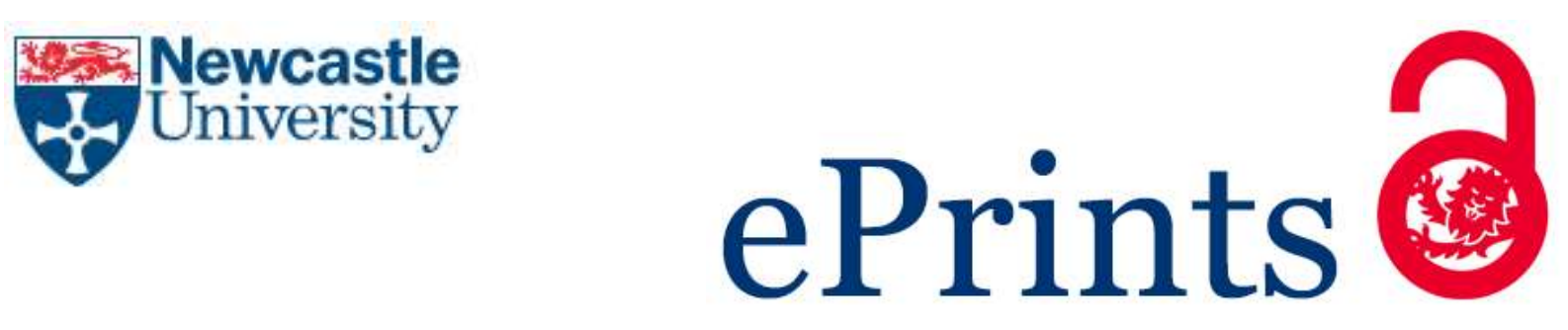

Philpott S. This Stillness, This Lack of Incident....Making Conflict Visible in West Papua. Critical Asian Studies 2018

\title{
Copyright:
}

This is an Accepted Manuscript of an article published by Taylor \& Francis in Critical Asian Studies on $7^{\text {th }}$ March 2018, available online: https://doi.org/10.1080/14672715.2018.1445537

Date deposited:

$22 / 03 / 2018$

Embargo release date:

07 September 2019

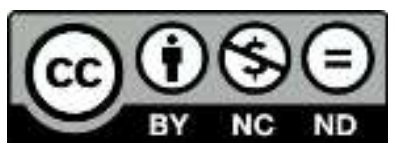

This work is licensed under a

Creative Commons Attribution-NonCommercial-NoDerivatives 4.0 International licence 


\section{This Stillness, This Lack of Incident....Making Conflict Visible in West Papua}

\section{Introduction:}

Since declaring its independence in 1945, Indonesian governments have been notably intolerant of secessionism, maintenance of Indonesia's territorial integrity an overriding concern. Only the incorporation of Papua ${ }^{1}$ (1969) and the invasion (1975), occupation, annexation and finally loss of East Timor by way of referendum (1999) have altered the borders of the post-colonial Indonesian state. The use of violence to overcome separatism has been a notable feature of Indonesian state responses to demands for independence in Aceh, East Timor and Papua. ${ }^{2}$ Moreover, the three conflicts are curiously interlinked. ${ }^{3}$ East Timor, a remnant of the Portuguese empire, was violently annexed by Suharto's government in part because of its fears that an independent enclave within the archipelago would offer symbolic if not material hope to the insurgencies in Aceh and Irian Jaya (as the province of Papua was then called). ${ }^{4}$

After the fall of Suharto, interim President Jusuf Habibie responded to international pressure about ongoing problems in East Timor by offering a referendum on its future. In 1999, the East Timorese voted for independence from Indonesia, becoming an independent nation in 2002. The successful negotiation of a peace settlement and special autonomy for Aceh arose from a complex series of factors including political changes in Jakarta and among the Free Aceh Movement (GAM) leadership, Indonesian military successes against armed

\footnotetext{
${ }^{1}$ The western half of the island of New Guinea was part of the Dutch colonial empire. Since its incorporation into Indonesia, the province has had a variety of different names and administrative structures. Currently the Indonesian half of the island is divided into two provinces, Papua and West Papua. Independence activists seek a unified nation that they most commonly refer to as West Papua. In this article, I will refer to the provinces as Papua (drawing no meaningful distinction between them) and to the Indigenous peoples as Indigenous or ethnic Papuans. I will refer to pro-independence activists as both Papuans and West Papuans and to the independent nation they seek as West Papua.

${ }^{2}$ Anderson 2015, 13

${ }^{3}$ Hernawan 2018, 14-15

${ }^{4}$ Schwarz 1994, 201; Heryanto 2006, 172
} 
independence fighters and the consequences of the 2004 tsunami. Both, in their time, were well-publicised, wars of attrition between the Indonesian state and separatist movements. The third, the campaign for an independent West Papua continues. Though estimates of casualties since Indonesia assumed control of the province in 1963 vary wildly, figures of between 150,000 and 500,000 West Papuan dead are often circulated in mainstream and social media. ${ }^{5}$ However, Indonesian control over access to and the topography and sheer size of the two provinces that make up the western half of the island of New Guinea make it extraordinarily difficult to substantiate any estimates of the numbers killed and even whether Indonesian policy can be rightly termed genocide. ${ }^{6}$ It is noteworthy that the International Parliamentarians for West Papua cites the figure of 500,000 killed since Indonesia assumed sovereignty. ${ }^{7}$ Unsurprisingly, the two provinces rank last on the Human Development Index for Indonesia. ${ }^{8}$ Yet the conflict in Papua has generated far less international interest and media coverage than either of the conflicts in Aceh or East Timor and is at times referred to as an invisible, secret or forgotten war. ${ }^{9}$ In no small part this is because successive Indonesian governments have blocked foreign journalists, NGOs and academics accessing Papua. ${ }^{10}$ This article explores the ways in which pro-independence activists are using social media to make conflict visible. For the purposes of this article, I am less interested in activist strategy than the ways the images selected and posted frame conflict, how conflict might be seen by social media consumers, and what needs to remain invisible for conflict to be understood by potential supporters in simple, vertical terms (a heavy handed state repressing those seeking independence).

\footnotetext{
${ }^{5}$ see Harvey 2014; Wenda 2015; Célérier 2010

${ }^{6}$ see Chauvel 2009; Anderson 2015, 44

${ }^{7}$ see: http://ipwp.org/human-rights-in-west-papua/

${ }^{8}$ Badan Pusat Statistik 2016; Anderson 2015, 14-16

${ }^{9}$ on the absence of coverage, see McGibbon 2006, 95

${ }^{10}$ Anderson 2015, 45-46
} 
It also examines the implications of activists, scholars and media producers designating a conflict invisible or forgotten and argues that forgetting and making invisible are active strategies on the part of powerful actors. Finally, I offer some reflections on the potential pitfalls of the current framing of conflict in Papua.

\section{West Papua: A Brief Background:}

When in 1949 the government of the Netherlands finally conceded defeat in its struggle to reinstate colonial rule over the country that had proclaimed itself the Republic of Indonesia in 1945, it refused to cede the easternmost part of the Netherlands Indies. That is, the Dutch government viewed the peoples of West New Guinea as culturally distinct from those of Indonesia's heartlands, refused to decolonise and commenced early preparations for an independent West New Guinea. For the Indonesian leadership this was simply unacceptable and they claimed jurisdiction over West New Guinea as the successor state to the former Dutch colonial empire and based on historical claims to sovereignty although the latter claim is dubious. ${ }^{11}$ Sukarno framed Indonesia as a nation incomplete with West New Guinea's future an ongoing component of his anti-colonial discourse. ${ }^{12}$

The status of West New Guinea chafed in relations between the new republic and, primarily, the Netherlands, the United States (US), the United Kingdom (UK) and Australia. Each of the western countries opposed an Indonesian takeover because of Cold War driven perceptions its president, Sukarno, was a radical nationalist too close to the left. However, by the late 1950s, recognising Indonesia's geostrategic importance and that US policy was encouraging Sukarno to embrace the Soviet Union, the UK and US dropped their opposition to Indonesia taking control of West New Guinea. Kennedy administration policy in favour of Indonesia

\footnotetext{
${ }^{11}$ Anti-Slavery Society 1990, 26

${ }^{12}$ Legge 1972, 247-51
} 
was decisive in the capitulation of the Dutch and its turning away from steering West New Guinea towards independence. ${ }^{13}$ Without the backing of the UK and the US, the Australian government had little choice but to abandon, in some humiliation, its vocal opposition to Indonesian ambitions in West New Guinea. ${ }^{14}$

The New York Agreement of August 1962 placed West New Guinea under temporary UN administration before transfer to Indonesia in 1963. The will of the West Papuan people was to be tested at the so-called Act of Free Choice some time prior to $1969 .{ }^{15}$ However, the UN, little interested in the plight of a people it regarded as primitive and incapable of selfgovernment, left overseer of the process, Ortiz Sanz, with a shoestring budget and skeletal staffing to run a highly complex operation. ${ }^{16}$ While the New York Agreement proposed that all men and women resident in West New Guinea (who were not foreign nationals) be enfranchised, some 800,000 people, Indonesian authorities acutely aware of Papuan opposition to being integrated into the republic hand-picked 1025 people to represent the interests of the population. The Act of Free Choice was conducted between July 14-August 2 1969 in eight assemblies (Merauke, Wamena, Nabire, Sorong, Fak, Manokwari, Biak, Port Numbay) with representatives separated from their families and communities and subjected to extreme pressure by Indonesian authorities to support integration. ${ }^{17}$ There was no secret ballot, rather the groups deliberated until they reached a unanimous decision. ${ }^{18}$ They, under enormous duress, declared for Indonesian sovereignty. Sanz expressed his deep reservations about the plebiscite in his report to the UN. ${ }^{19}$ Since Indonesia's annexation in 1969, the

\footnotetext{
13 for a detailed account, see, Drooglever 2009, 386-505

${ }^{14}$ Mackie 1963; Beddie 1968; Weisbrod 1967

15 Verrier 1986, 19-20; May 1978, 163; Asian Human Rights Commission 2013, 4-5

${ }^{16}$ Simpson 2003, 472

${ }^{17}$ Catholic Justice and Peace Commission of the Archdiocese of Brisbane 2016

${ }^{18}$ Hernawan 2018, 72-75

${ }^{19}$ May 1978, 198
} 
province has variously been called $\operatorname{Irian}^{20}$ Barat (West Irian), Irian Jaya (loosely Glorious Irian), and is now divided between Papua and West Papua. The absence of Papuan input into the New York Agreement and the conduct of the Act of Free Choice are key elements of Papuan discourses of injustice and form the basis of contemporary arguments for selfdetermination.

Even by the standards of Suharto's authoritarian state, Indonesia's rule in West Papua has been notably violent. ${ }^{21}$ The reasons for this are complex. Firstly, Indonesian nationalists committed to the model of the unitary republic have usually dealt harshly with separatist movements. ${ }^{22}$ Moreover, Indonesians know little about the activities of their government in Papua so there is minimal internal sympathy for the plight of ethnic Papuans. ${ }^{23}$ Secondly, a low level and largely ineffective armed pro-independence insurgency in Papua has encouraged a heavy-handed response from Indonesian security forces. ${ }^{24}$ Ethno-linguistic diversity undermines the insurgency's unity and singularity of purpose and the size of the province mitigates against efficient communication and joint logistics. ${ }^{25}$ Further complication arises from collaboration between elements of the resistance and Indonesian security forces. ${ }^{26}$ That is, material support lent by Indonesian forces encourages disputation between factions which enables the state to justify militarised responses to restore order. ${ }^{27}$ The general securitisation of ethnic Papuan discontent facilitates the suppression of even simple symbolic acts such as raising the Morning Star flag.

\footnotetext{
${ }^{20}$ Irian is possibly a Biak or other regional language word meaning 'hot land' but was appropriated by Indonesian nationalists and rendered as Ikut Republik Indonesia Anti-Nederlands (Join the Republic of Indonesia Anti-Netherlands).

${ }^{21}$ Aspinall and Berger 2001, 1004

${ }^{22}$ Reid 2010, 45

${ }^{23}$ Heryanto 2006, 21

${ }^{24}$ Schwarz 1994, 196; International Coalition for Papua 2017

${ }^{25}$ Aspinall and Berger 2001, 1014-15; McGibbon 2006, 29

${ }^{26}$ see Kirksey 2012

${ }^{27}$ see Kirksey 2012, 61-73
} 
Thirdly, transmigration has greatly altered Papua's demography with ethnic Papuans now possibly a minority of the province's population. ${ }^{28}$ Transmigration of people from, for example, heavily populated Java to more sparsely populated parts of the archipelago has been a long-standing Indonesian government policy. ${ }^{29}$ This has intensified Papuan concerns about extreme cultural dilution and sharpened political discourse concerning the intentions of the Indonesian government. $^{30}$

Fourthly, the world's largest gold mine and third largest copper mine are located in what the American owners called the Grasberg minerals district in the Sudirman mountain range of inland Papua. This vast undertaking, the workings of which are visible from space, has proven highly contentious amongst local peoples concerned about environmental damage and other forms of economic and social disruption. ${ }^{31}$ Indonesian state forces provide security for the mine and over the years have ensued many clashes between organised resisters and Indonesian forces. ${ }^{32}$ The owners of the mine, Freeport McMoRan are Indonesia's largest single tax payers. The combination of the mine's remoteness and financial importance have encouraged extremely sharp state responses to threats against its smooth operation. ${ }^{33}$

The effects of other dynamics are also important. Ariel Heryanto argues that Indonesian governments diligently attempt to cover up the violence perpetrated in Papua and routinely spread misinformation. ${ }^{34}$ On the one hand, repressive policies towards Indigenous Papuans requires the Indonesian government to maintain tight control over the access of journalists and the flow of information about the province. On the other hand, it is the supposed

\footnotetext{
${ }^{28}$ Elmslie and Webb-Gannon 2013, 146; Elmslie 2017

${ }^{29}$ Aspinall and Berger 2001, 1014

${ }^{30}$ Anderson 2015, 38

${ }^{31}$ Kirksey 2012, 11

${ }^{32}$ Kirksey 2012, 214; McGibbon 2006, 21)

${ }^{33}$ see, for example, Asian Human Rights Commission 2013

${ }^{34}$ Heryanto 2006, 21
} 
primitive state of ethnic Papuans that enables the framing of the provinces problems as primarily socio-economic (not political) and requiring state-intervention. ${ }^{35}$

\section{Invisible? The Conflict in West Papua:}

In keeping with the practices of most governments, Indonesia's have refrained from airing to international audiences the dirty laundry of its campaigns against the state's various others. In part this acknowledges the power of images of violence and death to provoke reactions that include surging antipathy towards perpetrators or sudden changes in perceptions of the contours of a conflict. Images of the dead can be particularly problematic and their meaning fluid as socio-political context changes. Certainly different communities potentially interpret images of conflict and violence distinctively but over time the politics of what images depict can be radically reinterpreted within a single community completely changing the meaning of an image or perhaps giving it force for the first time. ${ }^{36}$ The mass killing of communists in the mid-1960s largely took place in remote locations, often at night and with military and militia killers understanding it was clandestine work that was not to be publicised in any way. ${ }^{37}$ And yet, during its campaign against criminal gangs in 1983-84, Indonesian government forces made the murders of approximately 10,000 people a public spectacle, tossing “....corpses into crowded public places, such as bus terminals, schools, main roads, movie theatres or markets." Here they served to demonstrate "...the seemingly unlimited destructive power of the state...." and as warnings to dissidents. ${ }^{38}$

Foreign and some local journalists have also found travel to Indonesia's trouble spots, including Papua, extremely difficult. Suharto's New Order expelled foreign journalists on occasion and despite contemporary denials, restrictions remain on journalists travelling to and

\footnotetext{
${ }^{35}$ Asian Human Rights Commission 2013; Chauvel 2017

36 see Campbell 2004, 59-60 \& 63

37 Roosa 2016, 290

${ }^{38}$ Heryanto 2006, 21 
reporting on Papua. ${ }^{39}$ Ross Tapsell notes journalists there find themselves working in an environment of "sub-state authoritarianism" and are monitored by intelligence agencies and security forces. ${ }^{40}$ Journalists in the province claim they are harassed and intimidated by security forces. ${ }^{41}$ In April 2017, Reporters Without Borders called upon the Indonesian President to honour his commitment to open up the province to unfettered access by journalists. This plea came in the context of ongoing reports of visa denials, a growing blacklist of banned journalists and the deportation of two reporters in March. ${ }^{42}$ Other reports suggest journalists may only visit Papua under strict escorted supervision. ${ }^{43}$ Indonesian government management of media access means the state arbitrates the structure and content of broadcasting and controls information flows such that the media is a bulwark against political reform. ${ }^{44}$ Thus, governments carefully orchestrate Indonesia's (including Papua) lack of visibility in the international media. Indeed, John Pemberton describes New Order Indonesia as being essentially invisible in the international media, “...an ideal absence in which nothing...happens." ${ }^{45}$ However, the increasing penetration of mobile communications technologies and social media platforms make it increasingly difficult for the Indonesian government to control information flows.

The invisibility of Indonesian state violence also partially arises from conspiracies of blindness and silence on the part of its Western allies. The foundational event of the New Order, the extermination of real and alleged communists, was well recognised and highly visible to supportive allies of the new government, among them the US and Australia. Richard Tanter concludes that the silence in the Australian media about the mass murder

\footnotetext{
39 for discussion of curbs on media freedom, see Romano 2003

${ }^{40}$ see Radio New Zealand 2017b; Radio New Zealand 2017a; Tapsell 2016)

${ }^{41}$ Radio New Zealand 2017b

42 Radio New Zealand 2017a

${ }^{43}$ Hernawan 2018, 98

44 Atkins 2002, 176

${ }^{45}$ Pemberton 1994, 4
} 
which followed Sukarno's downfall “... is the point where anti-communism, the demands of the national security state, and... a deep measure of racism, fused to smother and then sever the connection to a shared humanity and moral responsibility."46 Tanter's findings of partial coverage of Indonesian affairs are consistent with Barry Lowe's ${ }^{47}$ comparison of reporting on Southeast Asian countries over a year in the broadsheet Sydney Morning Herald (SMH) and Australian Broadcasting Corporation (ABC) morning news radio in 1993 and 1968. His observations regarding Indonesia are noteworthy. In the later year, Indonesia generated significantly more coverage than either Malaysia or the Philippines. For the purposes of this article, it is analysis of the earlier year that is of relevance. Lowe observes:

In 1968 the $S M H$ coverage of Indonesia chiefly reflected that country's problems of nation building. The greatest number of stories (54) concerned the army's efforts to control separatist insurgencies in several islands and provinces. The resistance movement against Indonesian control in Irian Jaya was another focus of this theme. ${ }^{48}$

\section{Security concerns arising from the shared border between Australian administered Papua}

New Guinea and Indonesian occupied West New Guinea made for intense government and media interest. ${ }^{49}$ For Australian governments and policy-makers the question of Papua's future remains one of immense consequence. ${ }^{50}$ However, importance and consequence do not translate into engagement, discussion and making visible the province's problems. For example, the Lombok Treaty (2006) requires mutual respect of territorial integrity and specifically prohibits the parties, Australia and Indonesia, supporting separatism in the jurisdiction of the other party: Papua warrants no mention. There was no reference to it during February 2017 talks in Australia between President Joko Widodo and Prime Minister

\footnotetext{
${ }^{46}$ Tanter 2002

${ }^{47}$ Lowe 2000

${ }^{48}$ Lowe 2000, 122

${ }^{49}$ see Verrier 1986

50 see McGibbon 2006, 75-115, for a detailed account Australia-Indonesia relations over Papua.
} 
Malcolm Turnbull. According to Richard Chauvel, so complex and difficult are the issues, no senior Australian politician or bureaucrat will raise them. ${ }^{51}$ On this view, powerful actors authorise silence, invisibility and forgetting yet, ironically, create the opportunity for activist and critical scholarly narratives to inform wider opinion. ${ }^{52}$

Actual conflict may or may not be visible to all parties involved, but the consequences will be. Rumour, photography, online video, missing people, bodies, tortured and abused people returned to their communities as living warning, may singly or in combination play a part in making conflict visible and making shared the experience of violence. ${ }^{53}$ In Papua, Indonesian security forces harm and destroy some people publicly but the intent is not to demonstrate power over individual bodies but to communicate pain and suffering through the display of the mutilated. ${ }^{54}$ Moreover, where abuse, violence, arrest, and torture are primary strategies of government, internalised by local populations, actual visibility is of less importance. ${ }^{55}$

Externally, communities attempting to ignore or forget a conflict may confront some aspect of it becoming highly visible. In the Indonesian context, internationally televised footage of the 1991 Santa Cruz cemetery massacre explicitly confirmed the fact of state-sponsored violence against East Timorese civilians. ${ }^{56}$ As Jeffrey Goldfarb observes: "If a situation is defined as real, or appears and is perceived as real, on television, it becomes real in its consequences." ${ }^{, 57}$ For the Suharto government that meant an inability to return to invisibility the conflict in East Timor or erase it from the collective memory of a broader international audience seeing and remembering differently in the wake of the Cold War. For Indonesian

\footnotetext{
${ }^{51}$ Chauvel 2017

${ }^{52}$ McGibbon 2006, 83

${ }^{53}$ Hernawan 2018, 76-79 \& 91-92

${ }^{54}$ Hernawan 2018, 147

${ }^{55}$ Hernawan 2018, 114-155

${ }^{56}$ Anderson 2015, 31

${ }^{57}$ Goldfarb 2006, 121
} 
security forces in Papua, making conflict visible to its desired audiences resides in endless tension with the need to keep images of such out of wider circulation. ${ }^{58}$

\section{Strategies of Visibility:}

Arguably, the use of social media is changing the ways that Indigenous peoples communicate within and beyond particular communities about the common challenges they face. ${ }^{59}$ As Meredith Weiss observes, the global form and scope of the internet means it has been particularly useful for extending space for communication and coordination. ${ }^{60}$ Small groups of dedicated activists can widely disseminate information attaining a reach impossible prior to the advent of the internet and punching above their weight thanks to the force multiplier effect of information communication technologies. ${ }^{61}$ Social media also facilitates the triggering or intensification of conflict both online and offline. ${ }^{62}$ However, it is important that the capacity for activism not be overstated or romanticised because the infrastructure of the internet is designed and access to it controlled by states and private interests that may be "...eager to move the contest online and, perhaps, offstage." ${ }^{\prime 63}$ Recognising just this potential for dissent but also the state's facility for control, Indonesian Minister of Information and Communications Technology, Tifatul Sembiring, opined in July 2011 that the government should control social media to prevent organisation of anti-government protests. ${ }^{64}$

Nonetheless, the realm of digital communication may offer activists the best prospects of making the plight of Indigenous Papuan people more visible to non-specialist audiences. While Papua's communications infrastructure is poor, high and rising rates of social media penetration in Indonesia suggest online activism may be an important step in aligning the

\footnotetext{
${ }^{58}$ Hernawan 2018, 114-115

${ }^{59}$ United Nations 2008

${ }^{60}$ Weiss 2014, 92

${ }^{61}$ Bräuchler 2007, 330

${ }^{62}$ Bräuchler 2007, 333

${ }^{63}$ Weiss 2014, 92

${ }^{64}$ Weiss 2014, 102
} 
activities of West Papuan activists with others seeking reform in Indonesia. ${ }^{65}$ Yet, choices about framing and amplification are critical to the effectiveness of campaigns. Framing is not simply a matter of bringing attention to an issue but entails giving it context, meaning, significance such that it becomes understood by audiences in a particular way. ${ }^{66}$ The presentation and interpretation of events, discourses, and ongoing political scenarios raises questions of authenticity and authority: who speaks and for whom $?^{67}$ Moreover, irrespective of the potential for social media to extend the scope and influence of activism, it is most effective when cyber and physical worlds mesh, when online activism mobilises people to take steps in their material world, and when the online experience of shaping new identities and forming new alliances is made into concrete action. ${ }^{68}$ Courtney Radsch observes imagining a different future is only one dimension of activating the structural and material change key to realising the imagined future. "Even fantasises of liberation and revenge can help to preserve domination through dissipating collective energies in relatively harmless rhetoric and ritual." ${ }^{69}$ On this view, “....new media could merely augment existing patterns of polarisation and substantive depoliticisation in the long run." 70

Overwhelmingly, in social media West Papuan activists visually and verbally refer to a near absence of freedom, an inability to act in ways consistent with living in a free society. Discourses highlighting the absence of freedom and the violent suppression of dissent frame the struggle to a significant degree. In Facebook communities ${ }^{71}$, in YouTube hosted videos ${ }^{72}$

\footnotetext{
${ }^{65}$ Weiss 2014, 91

${ }^{66}$ Radsch 2016, 27

${ }^{67}$ Bräuchler 2007, 333

${ }^{68}$ Weiss 2014, 104

${ }^{69}$ Moore in Radsch 2016, 35

${ }^{70}$ Weiss 2014, 105

${ }^{71}$ A 'West Papua' search on Facebook produces tens of activist sites from within and outside of Papua suggesting support for independence across the world. One also finds pro-integration community sites that counter the narratives and discourses of violence and genocide.

72 A 'West Papua' search on YouTube reveals hundreds of clips of varying length and sophistication about the conflict in Papua. The first four are: 'West Papua's Hidden Fight for Independence'; 'Forgotten Bird of Paradise' (a multi-award winning, short documentary on the genocide); 'The Silent Genocide: West Papua'; and, 'West Papua: the Secret War in Asia' (a German production made by Friends of People Close to Nature).
} 
and on Twitter ${ }^{73}$, West Papuan activists routinely present an account of extraordinary violence directed at Indigenous Papuans and environmental catastrophe arising from mining, deforestation and other resource exploitation. These accounts frame the activities of the Indonesian state in discourses of rights repressed, democratic expression of the will to independence denied, and, ultimately, of the genocide of ethnic Papuans. Activist and academic sympathisers outside of Papua and Indonesia routinely reproduce such discourses and images, at times distorting and misrepresenting the causes, nature and consequences of conflict. $^{74}$

This is the point at which the extraordinary complexity of Papua's problems are collapsed into a simple narrative of a noble people struggling against a cold and brutal state. For example, Bobby Anderson argues that framing violence in Papua as a singular, vertical conflict between state and independence activists and fighters is highly problematic. Violence is differentiated through space and takes different forms including vigilantism, clan fights, domestic violence and common assaults making for a much more variegated conflict environment than that often presented by pro-independence activists. Indeed, Organisasi Papua Merdeka (OPM / Free Papua Movement) members rank lowly among those subjected to and surviving torture. ${ }^{75}$ While widespread discontent on the part of Indigenous Papuans is the overarching issue, the Indonesian state's antipathy towards separatism, transmigration, the presence of a vast mining operation and, acting like grit between these elements, the conduct of Indonesian security and military forces greatly complicate resolution of the province's problems.

\footnotetext{
${ }^{73}$ A 'West Papua' search on Twitter reveals about 50 different accounts including from individuals resident there. The same pattern of activist accounts being countered by pro-integrationist commentary is found on Twitter as Facebook.

${ }^{74}$ Anderson 2015, 41-43

75 Anderson 2015, 16-19; Hernawan 2018, 118-120
} 
Making conflict visible has often entailed symbolic and other kinds of political action. For example, more than 10k refugees crossed the border to PNG in May 1984 orchestrated by the OPM in response to violent military action after the raising of the Morning Star flag in Jayapura. The exodus was explicitly designed to attract international attention. ${ }^{76}$ Papuan activists have lobbied parliamentarians both within and outside of Indonesia and other extragovernment organisations. For example, the United Liberation Movement for West Papua (ULMWP) has observer status with the Melanesian Spearhead Group (while the state of Indonesia is an Associate Member). Gaining observer status meant different Papuan factions had to establish common positions, speak with a unified voice. ${ }^{77}$ Pacific Island governments periodically address the UN General Assembly (including the $71^{\text {st }}$ UN General Assembly in September 2016) and UN Human Rights Council to express their disquiet about Indonesian policy in Papua but the issue is generally divisive among Pacific states. ${ }^{78}$ The Pacific Islands Forum regularly makes statements of concern about conditions in West Papua and has been lobbied directly by the ULMWP. ${ }^{79}$

Activists have also demonstrated an understanding of how to amplify the effectiveness of small gestures through the mainstream media. Knowing a large media contingent was present in Bali, activists entered the Australian consulate and presented the Consul-General with a letter asking leaders attending the 2013 Asia Pacific Economic Forum meeting to press the Indonesian government to allow greater freedoms in the province. ${ }^{80}$ The action was brief, but meant that Papuan concerns cycled through the news however transiently. In September 2017, exiled activist, Benny Wenda, presented a petition at the UN allegedly signed by 1.8 million Papuans calling for West Papua to be put back on the UN's decolonisation committee

\footnotetext{
${ }^{76}$ Kirsch 2002, 59

${ }^{77}$ Hernawan 2016

${ }^{78}$ see Walsh 2016

${ }^{79}$ see, for example, Pacific Islands Forum Secretariat 2017; United Liberation Movement for West Papua 2017b)

${ }^{80}$ Bachelard 2013
} 
agenda. ${ }^{81}$ It is highly likely Wenda was aware that the petition could not be accepted given the committee's mandate but the 'event' attracted extensive international media interest. Activist exiles including Benny Wenda, also the subject of a recent documentary film, ensure lobbying efforts continue. ${ }^{82}$

Making the conflict visible also involves independence activists engaging in a range of discursive practices among themselves and with the wider population, that challenge standard approaches to the sharing of information. These include use of rumour, the supernatural and a distinctive millenarian cosmology that forms part of the activist framing of the conflict. ${ }^{83}$ The dissemination of rumour enables the expression of "...local concerns about political violence by transforming what is always present, although often unseen, into tangible form through language.” Rumour provides a means by which ethnic Papuans come to understand the Indonesian other through amplification of the experience of violence. ${ }^{84}$ However, Eben Kirskey notes that Kopassus ${ }^{85}$ personnel take advantage of Papuan cultural practices to conduct psychological operations and extend terror. For example, drawing upon local sorcery beliefs, operatives appear in different guises, creating the impression they have the power to navigate supernatural realms. Rumour serves to spread fear of what Kirksey describes as “hybrid specters of terror." He cites Michael Taussig to observe that such operatives are “...soldiers who are not really soldiers but more like ghosts flitting between the visible and invisible..."86 Even an observer as experienced as Kirksey finds this disorienting:

I struggled to distinguish West Papuan separatists from Indonesian nationalists, enemies from allies. In the face of complex entanglements, I was having difficulties

\footnotetext{
${ }^{81}$ Doherty and Lamb 2017

82 Information about the documentary can be found here: https://www.theroadtohomefilm.com/

${ }^{83}$ Anderson 2015, 5

${ }^{84}$ Kirsch 2002, 57

${ }^{85}$ Kopassus is the elite Special Forces unit of the Indonesian military, widely feared in West Papua and beyond.

${ }^{86}$ Kirksey 2012, 116
} 
sorting things out. A profound uncertainty is generated 'when existing networks of social knowledge are eroded by rumour, terror, or social movement' ${ }^{87}$

What drew me deeper into this research was the use of Twitter by activists supportive of West Papuan independence. As a regular Twitter user, I became aware of a small volume of traffic that depicted the problems in West Papua in the most graphic fashion. I am interested in the effects such visual depiction of the conflict has on perceptions of Papuans and Indonesians and on the nature of the conflict itself. That is, what work do the images themselves do irrespective of the intention of activists? What are the consequences of framing of the conflict as one of broken Papuan bodies? How does the visual production of conflict produce reverberations and resonances that intensify and/or dissolve opinions and attitudes? If at least some of the work of social media and the images it bears work beneath the level of explicit attention and encourage the sharpening of prejudices and fears about, for example, Muslims and contemporary conflict, what affective registers do images of the Papuan abject work in ${ }^{88}$ How, if at all, does the affective impact of imagery posted at Twitter win new supporters and induce established supporters of Papuan independence to act? That is, seeing is not a matter of pure vision but what becomes visible when the eye is placed in combination with specific contexts, discourses, objects and spaces. ${ }^{89}$ "To see...is not to apprehend the world, but it is to initiate a knowledge practice, to engage with and negotiate the various discursive conditions whereby the visible becomes visible." 90

Arguably, such images have a great deal of work to do. That is, photojournalism has set strong conventions for how 'we' look at 'them'. John Taylor notes that reports of horrors from abroad concentrate on the strangeness of others and frequently strengthen prejudices

\footnotetext{
${ }^{87}$ Kirksey 2012, 116

${ }^{88}$ on the issue of resonance in politics, see Connolly 2005

${ }^{89}$ Kearnes 2000, 335

${ }^{90}$ Kearnes 2000, 338
} 
that the cultures of others are different, primitive, or barbaric. Such journalism

"...emphasises disorder and even the impossibility of civil society in foreign countries."

Viewers of images of violence, disorder and death may have their feelings of repulsion about other cultures exacerbated when those depicted are black. ${ }^{91}$ While audiences external to Indonesia have seen very little of the troubles that blight the lives of ethnic Papuans, images circulated on Twitter and in other social media necessarily present peoples and ways of living quite different to those of a great many Twitter users.

Below I describe and analyse the content of four West Papua related Twitter accounts. I selected them for their prominence and for the diversity of their tweet activity. They range from the populist, sarcastic, graphic and most active (@PurePapua), to the serious-minded cooperative (@PapuaItuKita), to (@FreeWestPapua)with most followers and associated with well-known lobbyist in exile, Benny Wenda, to the elite (@ ulmwp) grouping targeting membership of the Melanesian Spearhead Group. Each is stylistically different and each distinctively draws attention to the government of and problems and abuses in the province. Searching Twitter for 'West Papua' produces 72 accounts of which some are no more than people noting West Papua in their personal profile, others that are anti-independence and / or pro-Indonesia, and yet others which are not obviously political. Nevertheless, around 50 have the images and content to suggest pro-independence sympathies. There are undoubtedly many more accounts concerned with West Papua but my interest lies not in identifying them or aggregating tweets but rather in apprehending how different tweeting styles produce the conflict in West Papua and the affective impact of them.

\footnotetext{
91 Taylor 1998, 129-131
} 
For example, the Twitter account of @PurePapua (121k tweets, 9.3k followers/ 129k tweets, $10.2 \mathrm{k}$ followers) ${ }^{92}$ is explicit in both (English) language and image, and refers to Indonesia as engaged in a genocidal, colonial military occupation. Both image and text produce Indonesia and its agents as exclusively addressing Papuans in and through violence. Most strikingly, this Twitter account is replete with images of broken and mutilated bodies highlighting colonial relations writing its violence directly on the body. These graphic, unsparing images are eye catching, and unequivocal in their condemnation of Indonesian forces. @PurePapua does not name victims, cite the locations or events at which alleged atrocities occur and so there is little certainty about the authenticity of the images. Reverse image checking suggests a small number are lifted from other times and contexts. However, this is the condition of possibility for visibility: the body and its colour are the aesthetic dimension of making the conflict visible and for asking audiences to make a determination as to the value of the Papuan culture and its claim for being preserved. @PurePapua also makes extensive comment upon and visual reference to environmental degradation with images of deforested landscapes and animals allegedly under threat of extinction because of unsustainable practices in the province. Yet, there is no identification of the areas denuded of trees. A claim that only 250 (very cute) tree kangaroos remain in the wild goes without verification. Entertainers such as Bob Marley are cited: "Better to die fighting for freedom than be a prisoner all the days of your life." Noam Chomsky's condemnation of western powers for their complicity in crimes against Papuan peoples reminds readers of his earlier activism on the part of the East Timorese. However, a pinned tweet on February 92016 reads: "Dear new followers: pls note I often take a shit on Indonesia \& absolutely love it, know what you're

\footnotetext{
${ }^{92}$ I have included two sets of figures for number of Tweets and followers. The first were current at the time this article was originally submitted to Critical Asian Studies in late April 2017 while the second are current at the time of resubmission in January 2018. It is notable that the number of followers has increased in each case though this does not necessarily translate to greater support for independence and may, in part, simply reflect growth in Twitter account holders some of who find their ways to such sites. Increases in followers of roughly $10 \%, 26 \%, 28 \%$ and $160 \%$ do outstrip growth in Twitter users however.
} 
getting yourself into \#FreeWestPapua.” One could read such a remark as acknowledgment that the account is not necessarily overtly concerned with factual reliability.

$@$ PapuaItuKita ${ }^{93}$ (c.2k tweets, 1.9k followers/ 2.5k tweets, 2.4 followers) is generally in Indonesian and focuses far more on demonstrations and events protesting aspects of Indonesian rule and development in Papua. For example, as I write protests are underway in Papua noting the $50^{\text {th }}$ anniversary of commencement of Freeport mining operations and calling for the closure of the mine. Images of protests are common in this account including some supporting West Papuan demands in other parts of the Indonesian archipelago. There are also images of outright violence but they are fewer and far less graphic than @ PurePapua. Events advertised are necessarily located in time and space. There are short clips of everyday life: women farming, children playing, innocent images which seem in part to highlight the simple, community-focused lives of many Papuans. The intrinsic merit of village life is a common theme developed in both text and image. The associated web site is largely in Indonesian and information rich. There are reports, articles and updates on topics such as the palm oil industry, deforestation, human rights, events, demonstrations, and government responses to issues and problems. The media section offers an extensive array of materials including commentary and blogposts from activists as well as newspaper articles from the (English language) Jakarta Post which are at times the work of Papua Itu Kita activists. The depleted shop section of the web site mirrors the absence of events listed for April 2017 (the time of writing). The 'who we are' statement makes clear that the site is run by volunteer activists concerned with justice and humanitarian outcomes in Papua.

Independence leader Benny Wenda at a website of the same name endorses @ FreeWestPapua (c. 31k tweets, 23.4 k followers/ 37.6k tweets, 30k followers). Given

\footnotetext{
${ }^{93}$ This translates as Papua Is Us or perhaps We are Papua. Either way the use of Kita is interesting as it is the inclusive form of We or Us.
} 
Wenda's status, this creates the impression of the Twitter feed being an 'official' account of the West Papuan independence movement. The Twitter account is largely in English and more narrowly focuses on demands for an independence plebiscite though not to the exclusion of other issues such as violence against Papuans, reports on environmental damage, news about demonstrations, censorship of news reporting, and calls for financial support. Images of the banned Morning Star flag are ubiquitous including on t-shirts, hats and other items of clothing, face paint, posters, murals and various electronic forms. The prevalence of Morning Star iconography, identification of international supporters, calls for backing for a plebiscite and attempts at corporate shaming including of British Petroleum (BP) and Rio Tinto deepen the sense of this being an 'official' account for the independence movement. A visit to the web site advertised @FreeWestPapua that prominently features a comment by Benny Wenda about his own experiences and his ongoing work to achieve a plebiscite buttresses the impression. The web site features news updates (highlighting abuses but also a variety of actions and events globally that suggest momentum for the independence cause). One can sign an Avaaz petition addressed to the UN Secretary General with just over 25,000 of the targeted 30,000 signatures achieved or another calling for open access for journalists with 48,500 signatures. An extensive list of resources includes films and documentaries, books, articles, and reports and music. The shop advertises the usual array of activist accessories including hats, t-shirts, bags, lapel badges, DVDs, CDs, posters and greeting cards. A Donate function seeks 200 people to make a monthly Paypal contribution to the work of activists and observes (at the time of writing) that 46 people have thus far signed up. The United Liberation Movement for West Papua (ULMWP) is the body formed from the unification of three factions of independence activists. Indonesian authorities have long claimed that there is no single independence movement in West Papua, characterising it as a series of disputatious gangs at loggerheads with each other. The formation of ULMWP in late 
2014 was in part and effort to counter this claim and to make possible a fresh bid for West Papuan membership of the Melanesian Spearhead Group. Compared with other accounts examined here, the @ulmwp Twitter account is little used with just 614 / 773 tweets logged since June 2015 and only 679 / 1771 followers. Unlike other accounts, there are very few images in the Twitter feed and those used are uncontroversial despite the occasional appearance of the Morning Star flag. The site is primarily an aggregator of news, comment and activist statements in both Indonesian and English. As such, the elite, lobbyist nature of the group, gives the Twitter feed a sense of earnestness and purpose. The ULMWP website has the appearance of sober formality. A summary of the case for independence hinges around the argument that the Act of Free Choice was in breach of key principles enshrined in Resolution 1541 (XV). The website provides information about each of the representatives, highlights the Westminster Declaration, and steers visitors to a small number of news reports and other information documents. No claims as to numbers killed, imprisoned, or tortured are made. However, compared to PapuaItuKita's site, ULMWP's lacks frequency of updates and volume of information.

Despite the many differences in content and style, underpinning the messages emanating from the Twitter accounts is the injustice suffered by the people of West Papua. Above all else, activists seek to make visible the suffering of Papuans arising from the fundamental injustice of their forced incorporation into the Indonesian nation-state. The call for a plebiscite (@FreeWestPapua and @ulmwp) puts activists on safe legal ground on two accounts. Firstly, the Act of Free Choice clearly fell short of any reasonable democratic standards. Secondly, activists routinely cite the refusal of international actors to honour UN General Assembly Resolution 1541 (XV) (1960) that recognised the democratic right of colonised peoples to seek independence. A common refrain in activist tweeting is that all that has befallen Papuan peoples arises from the failure of the international community to uphold 
the spirit and intention of the resolution. Therein lies a strong accusation of abandonment. There is minimal capacity for Papuans to overthrow Indonesian rule by force but seeking a peaceful, democratic pathway to independence means support from elite quarters such as the International Parliamentarians for West Papua and the International Lawyers for West Рариа. Both groups argue that the people of West Papua have a fundamental right to selfdetermination. Images of Papuan people demonstrating against continuing Indonesian rule and demanding a plebiscite on the future of the province powerfully link the discourses of injustice done and an unfulfilled right to self-determination and locate Indigenous Papuans on the 'right' side of the political divide. Pointing to support from parliamentarians, lawyers and some Pacific governments, activists invite uncommitted observers to see the justice of their cause. It is the alignment of past injustice, an imagined future, support from elite sources, and the suffering of an 'innocent' people that frames the political situation in West Papua activists want others to see.

For example, activists note the diminution of the Papuan population through transmigration, certainly a significant factor in the troubles in the province. However, other than as aggressors in the form of security forces, military or police, non-Papuans go unseen in proindependence social media. The wishes of something approaching half the population are unremarked, invisible. Arguably, such a strategy construes non-Papuans as irrelevant, perhaps even guilty of the crimes of the state by virtue of their "Indonesian" ethnicity. Indeed, activists (and some foreign supporters) tend to reduce the complex patterns of migration to the province to a kind of Javanese, Muslim invasion, ignoring the inflow of Christians from other parts of the archipelago.${ }^{94}$ Moreover, strategically disappearing nonIndigenous residents of Papua entails making invisible existing and potential dialogue

\footnotetext{
${ }^{94}$ Anderson 2015, 40
} 
between groups with different interests and stakes in the province. ${ }^{95}$ Thus, the visual politics of presenting the conflict imply victimhood and powerlessness. Citing Ghassan Hage, Jane Bennett notes that postcolonial societies have elevated the figure of the victim to a position of moral superiority. "...the 'abjected' becomes attractive at the moment when the 'abjector' is vilified and when it is assumed that 'in order not to be counted among sexists and racists one must become the phobic object of such subjects'."96 The figure of the abjected has been adopted by Papuan theologian Benny Giay as a means of incorporating local narratives suffering into a reimagined Papuan history. ${ }^{97}$

Inviting observers not to see non-Indigenous Papuans requires other visual strategies to ensure their invisibility. Overwhelmingly activists visually frame Indigenous Papuans as tribal peoples, often little attired or wearing items of clothing and other adornments that distinguishes them as different and separate from others that inhabit the province. Such visual markers romanticise the qualities of Indigenous, tribal life and hint at its superiority to the lives of city and town dwellers. It is noteworthy that Lush and Court Lodge, both producers of allegedly ethically sourced and manufactured products are prominent sponsors on the Free West Papua website. An aesthetics associating discourses of the organic, vegetarian, antivivisectionist, ethically sourced and traded products and the independence movement in West Papua suggests a politics of purity and an ethics of righteousness characterises the struggle of the Papuan peoples. Use of images of children, often accessorised in Morning Star adorned clothes or face paint, reinforces the strategy by inviting observers to see tribal life as innocent, simple, pure and uncorrupted. This is a dangerous strategy for two important reasons.

\footnotetext{
95 see, for example, Tebay 2009; Hernawan 2018, 199-223

${ }^{96}$ Bennett 2005, 5

${ }^{97}$ Hernawan 2018, 54
} 
Firstly, the trope of the noble native living close to nature, removed from the corrupting influences of modern life is one that traps Indigenous people in another time. Johannes Fabian in his well-known work on anthropological practice and discourse noted "...a persistent and systematic tendency to place the referent(s) of anthropology in a Time other than the present of the producer of anthropological discourse." 98 Of western colonising powers, Fabian noted their need for Time "...to accommodate the schemes of a one way history: progress, development, modernity (and their negative mirror images: stagnation, underdevelopment, tradition)." ${ }^{, 99}$ On this view, West Papuan rejection of modernising Indonesia and its development promises (despite its destructive and exploitative nature) may have the undesired consequence of fulfilling the expectations of some development discourses that Indigenous peoples are mired in tradition, unable to engage positively with modernity and in need of intervention to secure a more prosperous future. Here activist deployment of images of Indigenous people suffering that may generate distinctive affective registers of empathy among observers abruptly encounters a deeper, equally powerful assumption that Indigenous peoples require and deserve rehabilitation from beliefs and practices that leave them languishing in modernity's wake.

Secondly, implications of innocence, moral superiority and a singular Indigenous Papuan will to independence make invisible the complex complicity and collaboration between activists and an array of Indonesian and international forces noted by Eben Kirksey. That is, the fiction of an us and a them is revealed by close analysis of the compromises that can "...open up the field of possibility in situations of seeming impossibility." ${ }^{100}$ Kirksey uses the concept of entangled worlds to describe the architecture of politics in West Papua. Citing Anna Tsing, he notes that collaboration, clever engagements and beneficial alliances, usually temporary,

\footnotetext{
${ }^{98}$ Fabian 1983, 31

${ }^{99}$ Fabian 1983, 144

${ }^{100}$ Kirksey 2012, 6
} 
satisfy divergent, even hostile, interests. They create new interests and identities but not always to the benefit of all parties. ${ }^{101}$ "Freedom in entangled worlds means negotiating complex interdependencies, rather than promoting fictions about absolute independence." In these circumstances, "freedom fighters" appear in unexpected places within the architecture of power. "Strategic collaborations and compromises, rather than strategies of pure resistance, produced surprising victories."102 Distinguishing between allies and enemies, fact from fiction, is exceedingly difficult as a result. ${ }^{103}$ Indeed, Indonesian security forces have long provoked tensions between resistance groups, lent them material support to facilitate conflict between them and against Indonesian forces thus providing the rationale for further militarised action. The complexity and uncertainty noted by Kirksey are lost in activists' correspondingly simple strategies to reveal and make visible violence against Indigenous Papuans. That is, activist social media strategies tend to work in predictable binaries: perpetrators and victims; violence and suffering; powerful and powerless; guilty and innocent; barbarity and nobility; enslavement and freedom. As such, the social media production of the broken bodied, marginalised, innocent, Indigenous Papuan depicts a tension in anti-colonial discourses. Indonesia is at once produced as barbaric in that the state kills, lacks compassion and reason and yet modern in its capacities for organised repression, bureaucracy, and the cold logic of transmigration that makes disappear Papuan people and culture. In activist strategies, epistemic forms of violence give way to more direct, physical accounts of Indonesian state violence although the greater danger perhaps lies in the integration of Papuan peoples into a singular, development-driven, Indonesian identity. For example, in 1985 the then Indonesian Transmigration Minister observed: “...we will try to realise what has been pledged, to integrate all the ethnic groups into one nation, the

\footnotetext{
${ }^{101}$ Kirksey 2012, 6

102 Kirksey 2012, 15 \& 18

${ }^{103}$ Kirksey 2012, 95
} 
Indonesian nation...The different ethnic groups will in the long run disappear... and there will be one kind of man."104

The social media production of Indonesia as a ruthless and barbaric colonial oppressor may have an unintended consequence of confirming Orientalist prejudices by locating it beyond the reach of rational political discourses. For instance, Gerry van Klinken argues:

“....Indonesia's most intractable political problem today is the strength of commitment within the 'deep state' to the violent suppression of dissident views." ${ }^{105}$ While van Klinken confines his observation to the nature of the state, the almost inevitable association of Indonesia with Islam draws the problems of West Papua into broader discourses of civilizational clash that characterise contemporary politics. The boundaries between civilisation and barbarism, between us and them, have what Derek Gregory calls performative force, conjuring up an architecture of enmity. ${ }^{106}$ These wider discourses produce irreconcilable foes, enemies whose very existence demands unstinting efforts towards their annihilation. For the supposed forces of civilisation, there can be no understanding, dialogue, or engagement with those deemed to be evil. West Papuan activists producing an Indonesian state that seems immune to efforts at its reform may successfully position Indonesia as essentially barbarous. However, what may result is an affective response of inevitability (of conflict between Christian "Papuans" and Muslim "Indonesians"), resignation (to such conflict being entrenched), even defeat (resolution is impossible given the dynamics between the parties), among sympathetic observers. The risk, for activists, is that potential supporters regard efforts towards an independent West Papua as certain to fail because Indonesia can only respond with violence and barbarism. As such, attempts at dialogue and negotiation are futile. On this view, activist

\footnotetext{
${ }^{104}$ Elmslie and Webb-Gannon 2013, 158; see also Anderson 2015, 38

${ }^{105}$ Van Klinken 2014, 177

106 Gregory 2004, 48 
social media produces an over-determined Indonesia and yet one so simplified that there is no hint of Jakarta's divergent and contradictory interests and policies.

Jane Bennett observes that in "...the era of postcolonialism, trauma has acquired a certain cachet...a moral authority...it has become politically desirable to identify with victims of oppression...The victims of oppression or terror...become ciphers of good, simply by virtue of having been subjected to evil.."107 Arguably, social media activists supporting West Papuan independence understand the affective potential of producing Indigenous Papuans as innocent victims. However, those using particularly graphic images ignore ethical issues arising from their use. On the one hand, one could argue that there is a "truth value" or an educative function to the circulation of images of bodies profoundly damaged, or worse, by violence. On the other hand, Yazir Henri argues that seeking an affective response through use of an image of a 'victim' violates the dignity of the subject, “....reducing him or her to a cipher of victimhood and...enacting a further form of colonization." For him there is no educative value in such a strategy as both producer and viewer engage in an unreflective and unproductive sympathy but develop no understanding of the violence "...or of the differential involvement in that violence." 108 As such, and notwithstanding the evidence of ongoing statesponsored violence, it may be that social media activists are engaged in the production of a spectacle of violence rather than creating the conditions of making visible the plight of Indigenous Papuans. This is a reminder that the internet is not merely a simple platform but a “... social process fraught with 'images, ideological symbols and representations of power.' As such, new media activism centres around the construction and assertion of identities, enabling a range of new forms of resistance and empowerment." ${ }^{109}$ In other words, perhaps

\footnotetext{
${ }^{107}$ Bennett 2005, 26-27

108 see Bennett 2005, 63-64

${ }^{109}$ Weiss 2014, 104
} 
having not yet mastered the enabling elements of social media, activists are at risk of audiences not seeing what it is that they are attempting to make visible.

\section{Conclusion:}

The conflict in Papua is of enduring interest to the governments and residents of Australia and a number of Pacific Island states but it is otherwise little covered in mainstream international media outlets. However, the advent of social media and mobile devices for its use has begun to change the prospects of making the conflict in Papua visible, a point noted by the ULMWP. ${ }^{110}$ Activists are adopting different social media strategies in attempting to make visible violence in the province and to promote the cause of independence. The September 2017 attempt to present the petition to the UN demonstrates a sound understanding of how conventional lobbying can spark news media interest that can be further amplified through social media networks. Nonetheless, the simplification of the conflict into a hard-pressed, out-gunned but noble Indigenous population attempting to hold out against a remorseless, ruthless and heavily armed state apparatus strips the conflict of its immense complexity and, arguably, fails to create the conditions whereby the visible becomes visible. Moreover, social media activists producing the Indonesian government as beyond reason and interested only in completing the genocide allegedly underway for over half a century may have the unintended consequence of discouraging the bearing of witness because the task of engaging the Indonesian state seems pointless. This may inadvertently play into the hands of Indonesian governments that have long worked to dampen interest in the province's problems. Activists may well need to more deeply consider the nature of the social process in which they are engaged and reflect not just on the affective possibilities of establishing ethnic Papuans as victims but the considerable costs of failing to better attend to

${ }^{110}$ see United Liberation Movement for West Papua 2017 
the contours and dynamics of the conflict in Papua. It is a truism that attention spans are short in the realms of social media: activists have much to gain by well understanding how interest is converted into action.

(8806 words without bibliography, author's name, contact details, abstract, biographical data, disclosure, keywords)

(9952 with bibliography)

\section{References}

Anderson, Bobby. 2015. Papua's Insecurity: State Failure in the Indonesian Periphery In Policy Studies, edited by Dieter Ernst and Marcus Mietzner. Honolulu: East-West Center.

Anti-Slavery Society. 1990. West Papua: Plunder in Paradise. In Indigenous Peoples and Development Series, edited by Alan Whittaker. London: Anti-Slavery Society.

Asian Human Rights Commission. 2013. The Neglected Genocide: Human Rights Abuses Against Papuans in the Central Highlands, 1977-1978. Hong Kong.

Aspinall, Edward, and Mark T. Berger. 2001. "The Break-up of Indonesia? Nationalisms after Decolonisation and the Limits of the Nation-State in Post-Cold War Southeast Asia." Third World Quarterly 22 (6):1003-1024.

Atkins, William. 2002. The Politics of Southeast Asia's New Media. London and New York: Routledge.

Bachelard, Michael. 2013. "Australian Consulate in Bali Faces Questions Over Asylum Claims of Papuan Activists." The Sydney Morning Herald, 7 October. Accessed 31 March 2017. http://www.smh.com.au/federal-politics/political-news/australianconsulate-in-bali-faces-questions-over-asylum-claims-of-papuan-activists-201310072v3nk.html.

Badan Pusat Statistik. 2016. Indeks Pembangunan Manusia Menurut Provinsi, 2010-2016 (Metode Baru). edited by Badan Pusat Statistik. Jakarta: Badan Pusat Statisik

Beddie, B.D. 1968. "Australian Policy Towards Indonesia." Australian Outlook 22 (2):123140. doi: 10.1080/10357716808444310.

Bennett, Jane. 2005. Empathic Vision: Affect, Trauma, and Contemporary Art. Edited by Mieke Bal and Hent de Vries, Cultural Memory in the Present. Stanford: Stanford University Press.

Bräuchler, Birgit. 2007. "Religious Conflicts in Cyberage." Citizenship Studies 11 (4):329347. doi: 10.1080/13621020701476012.

Campbell, David. 2004. "Horrific Blindness: Images of Death in Contemporary Media." Journal for Cultural Research 8 (1):55-74. doi: 10.1080/1479758042000196971.

Catholic Justice and Peace Commission of the Archdiocese of Brisbane. 2016. We Will Lose Everything: A Report on a Human Rights Fact Finding Mission to West Papua.

Célérier, Philippe Pataud. 2010. "Autonomy Isn't Independence: Indonesian Democracy Stops in Papua " Le Monde Diplomatique, June.

Chauvel, Richard. 2009. "Genocide and Demographic Transformation in Papua." Inside Indonesia, 20 September. 
Chauvel, Richard. 2017. Indonesia, Australia and the Papua Question In Talking Indonesia, edited by Jemma Purdey. Melbourne: Indonesia at Melbourne.

Connolly, William. 2005. "The Evangelical Capitalist Resonance Machine." Political Theory 33 (6):869-886.

Doherty, Ben, and Kate Lamb. 2017. "West Papua Independence Petition is Rebuffed at UN." The Guardian, 30 September Accessed 1 December 2017.

https://www.theguardian.com/world/2017/sep/30/west-papua-independence-petitionis-rebuffed-at-un.

Drooglever, Pieter. 2009. An Act of Free Choice: Decolonisation and the Right to SelfDetermination in West Papua. Oxford: Oneworld Publications.

Elmslie, Jim. 2017. "The Great Divide: West Papuan Demographics Revisited; Settlers Dominate Coastal Regions but the Highlands Still Overwhelmingly Papuan." The Asia-Pacific Journal 15 (2):1-12.

Elmslie, Jim, and Camellia Webb-Gannon. 2013. "A Slow-Motion Genocide: Indonesian Rule in West Papua." Griffith Journal of Law \& Human Dignity 1 (2):142-166.

Fabian, Johannes. 1983. Time and the Other: How Anthropology Makes its Object. New York: Columbia University Press.

Goldfarb, Jeffrey C. 2006. The Politics of Small Things: The Power of the Powerless in Dark Times. Chicago: The University of Chicago Press.

Gregory, Derek. 2004. The Colonial Present: Afghanistan, Palestine, Iraq. Malden, MA: Blackwell Publishing.

Harvey, Gemima. 2014. "The Human Tragedy of West Papua." The Diplomat, 15 January 2014.

Hernawan, Budi. 2016. "ULMWP and the Insurgent Papua." Live Encounters, December, 2223.

Hernawan, Budi. 2018. Torture and Peacebuilding in Indonesia: The Case of Papua, Contemporary Southeast Asia. Abingdon, Oxon: Routledge.

Heryanto, Ariel. 2006. State Terrorism and Political Identity in Indonesia: Fatally Belonging. London: Routledge.

International Coalition for Papua. 2017. Human Rights in West Papua 2017. Wuppertal, Geneva: International Coalition for Papua.

Kearnes, M.B. 2000. "Seeing is Believing is Knowing: Towards a Critique of Pure Vision." Australian Geographical Studies 38 (3):332-340.

Kirksey, Eben. 2012. Freedom in Entangled Worlds: West Papua and the Architecture of Power. London: Duke University Press.

Kirsch, Stuart. 2002. "Rumour and Other Narratives of Political Violence in West Papua." Critique of Anthropology 22 (1):53-79.

Klinken, Gerry van. 2014. "No, The Act of Killing is Not Unethical." Critical Asian Studies 46 (1):176-178.

Legge, J.D. 1972. Sukarno: A Political Biography. North Sydney: Allen \& Unwin Australia Pty. Ltd.

Lowe, Barry. 2000. "Australian news media constructing Asia: a case stud of Malaysia, Indonesia and the Philippines." In Foreign Devils and Other Journalists, edited by Damien Kingsbury et al, 111-131. Clayton, Victoria: Monash Asia Institute.

Mackie, J.A.C. 1963. "Australia and Indonesia 1945-60." In Australia in World Affairs 195660, edited by N. Harper and G. Greenwood. Melbourne: F.W. Cheshire Pty. Ltd.

May, Brian. 1978. The Indonesian Tragedy. Singapore: Graham Brash (Pte) Ltd.

McGibbon, Rodd. 2006. Pitfalls of Papua: Understanding the Conflict and its Place in Australia-Indonesia Relations. Double Bay, NSW: Lowy Institute for International Policy. 
Pacific Islands Forum Secretariat. 2017. Forum Communiqué: Forty-Eighth Pacific Islands Forum. Apia, Samoa: Pacific Islands Forum.

Pemberton, John. 1994. On the Subject of 'Java'. Ithaca: Cornell University Press.

Radio New Zealand. 2017a. "Jokowi Urged to Honor Promise to Free Up Media Access to West Papua." Radio New Zealand, Last Modified 5 April 2017, accessed 7 April http://www.radionz.co.nz/international/pacific-news/328231/jokowi-urged-to-honorpromise-to-free-up-media-access-to-west-papua.

Radio New Zealand. 2017b. "West Papua Media Access Still Fettered- PFF." Radio New Zealand, Last Modified 16 February, accessed 7 April. http://www.radionz.co.nz/international/pacific-news/324673/west-papua-mediaaccess-still-fettered-pff.

Radsch, Courtney C. 2016. Cyberactivism and Citzen Journalism in Egypt: Digital Dissidence and Political Change. Edited by Derrick Cogburn, Information Technology and Global Governance. New York: Paglrave Macmillan.

Reid, Anthony. 2010. Imperial Alchemy: Nationalism and Political Identity in Southeast Asia. Cambridge: Cambridge University Press.

Romano, Angela. 2003. Politics and the Press in Indonesia: Understanding and Evolving Political Culture. London: RoutledgeCurzon.

Roosa, John. 2016. "The State of Knowledge About an Open Secret: Indonesia's Mass Disappearances of 1965-66." The Journal of Asian Studies 75 (2):281-297. doi: 10.1017/S0021911816000474.

Schwarz, Adam. 1994. A Nation in Waiting: Indonesia in the 1990s. St Leonards, NSW: Allen \& Unwin.

Simpson, Brad. 2003. "Power, Politics, and Primitivism: West Papua's Struggle for SelfDetermination." Critical Asian Studies 35 (3):469-475.

Tanter, Richard. 2002. "Witness Denied." Inside Indonesia 71.

Tapsell, Ross. 2016. The Indonesian Media. In Talking Indonesia, edited by Ken Setiawan. Melbourne: Indonesia at Melbourne.

Taylor, John. 1998. Body horror : photojournalism, catastrophe, and war, Critical image. Washington Square, N.Y.: New York University Press.

Tebay, Neles. 2009. Dialogue Between Jakarta and Papua: A Perspective From Papua. edited by Otmar Oehring. Aachen: Pontifical Mission Society.

United Liberation Movement for West Papua. 2017a. "Background." accessed 21 April. https://www.ulmwp.org/background.

United Liberation Movement for West Papua. 2017b. ULMWP Appeals to the Pacific Islands Forum to Support West Papuan Self-Determination

United Nations. 2008. Declaration on the Rights of Indigenous Peoples. United Nations.

Verrier, June. 1986. "The Origins of the Border Problem and the Border Story to 1969." In Between Two Nations: The Indonesia-Papua New Guinea Border and West Papua Nationalism, edited by R.J. May, 18-48. Bathurst, N.S.W.: Robert Brown and Associates (Aust) Pty. Ltd.

Walsh, Patrick M. 2016. "The Pacific is Divided on West Papua." East Asia Forum, 5 November. http://www.eastasiaforum.org/2016/11/05/the-pacific-is-divided-on-westpapua/.

Weisbrod, H. 1967. "Sir Garfield Barwick and Dutch New Guinea." Australian Quarterly 34 (2):24-35.

Weiss, Meredith L. 2014. "New Media, New Activism: Trends and Trajectories in Malaysia, Singapore and Indonesia." International Development Planning Review 36 (1):91109. doi: 10.3828/idpr.2014.6. 
Wenda, Benny. 2015. "The Indonesian Government Cannot Stand in the Way of West Papuan People." The Guardian, 24 June 2015. Accessed 24 June 2015.

http://www.theguardian.com/commentisfree/2015/jun/24/the-indonesian-governmentcannot-stand-in-the-way-of-west-papuan-people. 